\title{
The Effect of Handling Complaint and Hospital Service Quality on Patient Satisfaction and Loyalty
}

\author{
Siti Fatonah ${ }^{1^{*}}$, Heny Palupi ${ }^{2}$ \\ ${ }^{*}$ Correspondence Author : siti.fatonah@stie-aub.ac.id
}

1,2 STIE AUB Surakarta, Indonesia

IN DEXING

Keywords:

Hospital Handling

Complaint;

Hospital Service

Quality;

Patient Satisfaction;

Patient Loyalty.

Kata kunci:

Keluhan Penanganan

Rumah Sakit;

Kualitas Pelayanan

Rumah Sakit;

Kepuasan Pasien;

Loyalitas Pasien.

\begin{abstract}
A B S T R AC T
The aim of this research is to investigate the effect of handling complaints and hospital service quality on patient satisfaction and patient loyalty. The sample of this study was patients at hospitals in the Sragen Regency, Central Java. This study used a quantitative research design to test the hypothesis research model. The total sample in this study was 90 patients and it used random sampling as the technique sample. Path analysis was used to test the research model. The results of this study show that there are positive significant effects between handling complaints and patient satisfaction. Second, there are positive significant effects between hospital service quality and patient satisfaction. Finally, there are positive significant effects between patient satisfaction and patient loyalty.
\end{abstract} Tujuan dari penelitian ini adalah untuk mengetahui pengaruh penanganan keluhan
dan kualitas pelayanan rumah sakit terhadap kepuasan pasien dan loyalitas pasien.
Sampel penelitian ini adalah pasien di RSUD di Kabupaten Sragen, Jawa Tengah.
Penelitian ini menggunakan desain penelitian kuantitatif untuk menguji model
penelitian hipotesis. Jumlah sampel dalam penelitian ini adalah 90 pasien dengan
teknik pengambilan sampel secara random sampling. Analisis jalur digunakan untuk
menguji model penelitian. Hasil penelitian ini menunjukkan bahwa terdapat
pengaruh yang signifikan positif antara penanganan keluhan dengan kepuasan
pasien. Kedua, terdapat pengaruh signifikan positif antara kualitas pelayanan rumah
sakit dan kepuasan pasien. Akhirnya, ada efek signifikansi positif antara kepuasan
pasien dan loyalitas pasien.
O 2020 JMMR. All rights reserved

\section{INTRODUCTION}

Service satisfaction is an important factor for service companies in creating customer loyalty (Hur et al. 2013). Developing and implementing the best strategy in achieving customer satisfaction can increase customer loyalty (Bowen and Chen 2001). Furthermore, It is said that service companies need to make use of databases to draw the characteristics of their customers.

The problems usually faced by service companies are very complex. One of them is a health service provider. In the health sector, the ability of service providers to retain customers is an important strategy (Bowen and Chen 2001). Thus, service providers are required to always maintain user satisfaction by improving the quality of their services so that loyalty will be maintained. The same applies to services in the health sector. Hospitals, which are one of the sectors engaged in services, now need to be careful to determine patient needs in an effort to fulfill desires and increase service satisfaction. Providing the best quality service is not something easy for hospital service managers because the services provided by the hospital are related to the quality of life of its patients so that if there is an error in medical action it can have a negative impact on the patient. The study developed by Wu and 
$\mathrm{Hu}$ (2012) explained the importance of the hospital in improving the process capability of their business activities in responding to patients.

Hospitals as part of the health system for the community are required to improve the quality of services through the provision of attractive facilities, good services and optimal handling patients' complaints. In addition, hospitals are also a competitive health service provider sector. So, it needs to be managed by someone who has an entrepreneurial spirit who is able to create creativity, excellence in service quality, excellence in service innovation and responsive to complaints from patients.

This study examines the mediating role of customer satisfaction in the relationship between handling complaints and hospital service quality on patient loyalty. Several previous studies have found the importance of customer satisfaction in increasing customer loyalty so that the topic of this study is still an interesting issue for the further study. This study measures customer satisfaction that is focused on developing and testing instruments for measuring patient satisfaction. This is an interesting topic because patient satisfaction is a mediation in achieving customer loyalty.

This study aims to examine the effect of Handling Complaint and Hospital Service Quality on customer satisfaction. This study also examines the mediating role of customer satisfaction in the relationship between Hospital Handling Complaint and Hospital Service Quality on customer loyalty. The sample in this study were patients at the Hospital in Sragen Regency, Central Java. This study also empirically proves previous research that discusses SERVQUAL.

\section{Theoretical Basis and Hypothesis Development}

\section{The Relation of Handling Complaint on the Patient Satisfaction}

One of the reasons why there is a moving of customers from one service hospital to another is because the customer is not satisfied with solving problems or how to deal with problems from the hospital to the patients. Dealing with customer complaints over the way services are provided by a hospital (Tronvoll 2007). When patients feel dissatisfied with what is received or when services are provided by service providers, they will have problems. The patient may respond by moving to another service provider.

Handling patient complaints from the hospital is currently one of the main keys of a hospital that can continue to grow and develop, because if patients do not receive good service when submitting complaints, patients will easily move to another hospital that is considered to provide good services through unique characteristics in handling patient complaints (Skalen et al. 2016).

Complaint handling is an embodiment of strategies and competing techniques provided by the hospital. Complaint handling can be used as an important instrument in controlling the conflict between the hospital and the patient about dissatisfaction (Kau and 
Loh 2006). The handling of complaints by the hospital is a tool to increase the profit of the hospital (Salazar et al. 2013).

Based on the description above, the following research hypothesis was developed:

\section{H1 : Handling Complaints have a positive effect on patient satisfaction}

\section{The Relation of Hospital Sservice Qquality on the Patient Satisfaction}

Patient satisfaction occupies an important position in the service sector, including hospital services. Satisfaction is a benefit that can be generated from the hospital in providing facilities and services to patients.

The Study developed by Lim et al. (2018) revealed that service quality is positively related to patient satisfaction as well as satisfaction and utilization has a significant positive effect on financial performance. The results of other analyzes also provide support for previous findings that the quality of hospital services is positively related to patient satisfaction.

Several previous studies examined the relationship of service quality and patient satisfaction (Vinagre and Neves 2008). Several previous studies have also evaluated the relationship between service quality, patient satisfaction, hospital operational utilization measures, and hospital financial performance (Duggirala et al. 2008). Therefore, the basic objective of this study was to examine previous studies by investigating additional relationships between patient complaints, quality of service, satisfaction and patient loyalty.

Quality and increasing service satisfaction are important parts of the marketing strategy. However, this study focuses on hospital services in the aspect of marketing activities. Patient services can be defined as services or services purchased by patients with the aim of achieving their satisfaction.

Based on the description above, the following research hypothesis was developed:

\section{H2 : Hospital Service Quality has a positive effect on patient satisfaction}

\section{The Relation of Patient Satisfaction on the Patient Loyalty}

Patient behavior as part of human activities is always changing according to the environmental and social influences where he is. Loyalty means that customers continue to make purchases on a regular basis. Study by Mithas et al. (2006) defines Loyalty as the customer's willingness to continue to support a hospital in a long-term time, to buy and use its services on an exclusive basis of love and voluntarily recommend the hospital services to others. Customer loyalty according to Griffin (2005) is defined as:

"when a customer is loyal, he or she exhibits purchase behavior defined as non-random purchase expressed over time by some decision-making unit".

Customer loyalty is an encouragement of behavioral to make repeated purchases and to build customer loyalty to a service produced by the business entity which takes a long time 
through a repetitive purchasing process. Oliver Richard (1997) defines customer loyalty as a deep commitment formed by the customer to repurchase or reuse the service consistently in the future, even if there are situational influences and other marketing efforts that could be competent to trigger the moving behavior.

Hospital customer satisfaction affects patient loyalty (Wu 2011). In the competitive health industry, the impact of hospital image on patient attitudes and behavior is an important issue. Service quality and patient satisfaction are the main avenues for impacting hospital brand image on patient loyalty. Moreover, the study by Fatima et al. (2018) explained that health care providers need to strive to provide better health services to their customers. Furthermore, it is said that better service quality tends to build satisfaction and loyalty among patients. Aspects of health service quality (i.e., physical environment, customer friendly environment, responsiveness, communication, privacy and safety) are positively related to patient loyalty mediated through patient satisfaction.

Based on the description above, the following research hypothesis was developed:

\section{H3 : Patient Satisfaction has a positive effect on patient loyalty}

The research model was developed as follows:

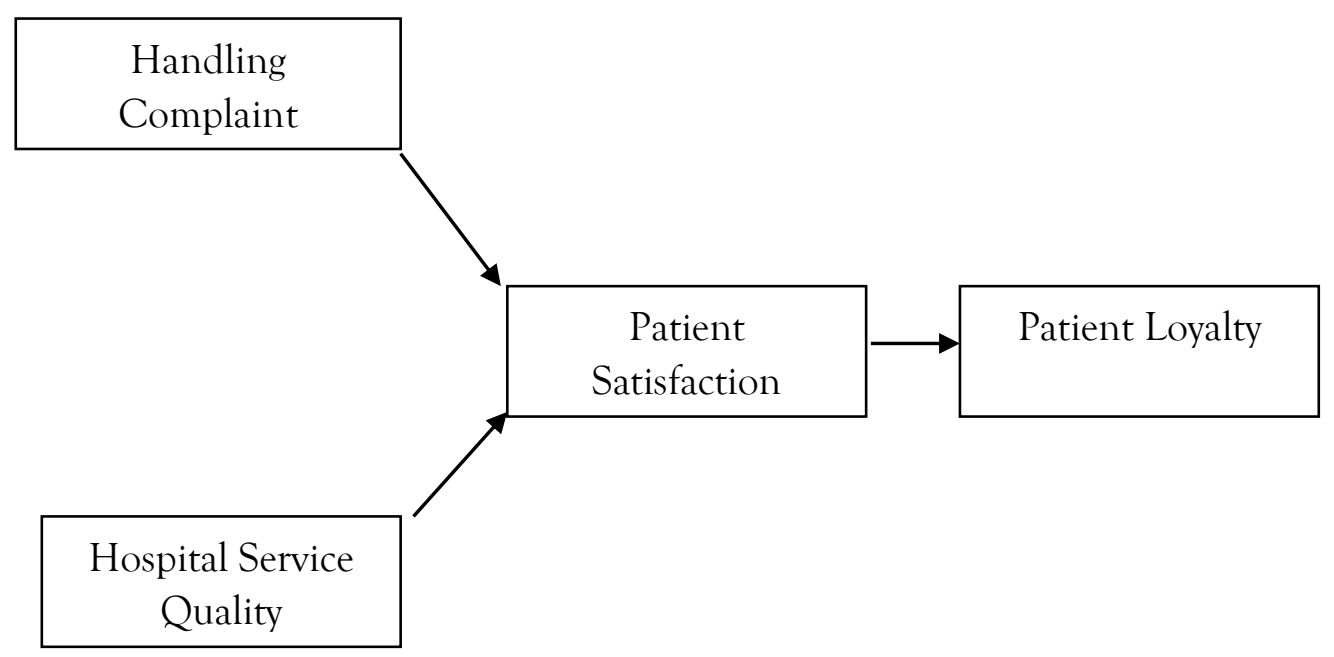

Figure 1. Empirical Research Model

\section{RESEARCH METHOD}

This study used a quantitative design. It examined the empirical research model and the correlational relationship among research variables. The research approach with a quantitative design was used to test the research hypothesis. This study develops 3 research hypotheses as developed in the empirical research model above. Meanwhile, the sample in this study were patients who used hospital services in Sragen Regency. Primary data selected in this study were collected using a survey through a questionnaire conducted on patients. The number of samples studied was 90 samples. While the sampling technique was carried out by purposive sampling. 


\section{Respondent Description}

The following is a summary description of the research respondents as shown in table $1 .:$

Table 1. Respondent Description

\begin{tabular}{lcc}
\hline Age (years) & Number & Percent \\
\hline $21-30$ & 8 & $8.89 \%$ \\
\hline $31-40$ & 12 & $13.33 \%$ \\
\hline $41-50$ & 35 & $38.89 \%$ \\
\hline $51-60$ & 10 & $11.11 \%$ \\
\hline$>60$ year & 25 & $27.78 \%$ \\
\hline Gender & & \\
\hline Male & & \\
\hline Female & 50 & $55.56 \%$ \\
\hline & 40 & $44.44 \%$ \\
\hline Profession & & \\
\hline Farmer & & \\
\hline Trader & 50 & $55.56 \%$ \\
\hline Entrepreneur & 20 & $22.22 \%$ \\
\hline Government employee & 10 & $11.11 \%$ \\
\hline Education level & 10 & $11.11 \%$ \\
\hline Elementary school & & \\
\hline Junior high school & & \\
\hline Diploma & 15 & $16.67 \%$ \\
\hline Undergraduate & 30 & $33,33 \%$ \\
\hline Postgraduate & 10 & $11.11 \%$ \\
\hline & 20 & $22.22 \%$ \\
\hline
\end{tabular}

\section{Validity Test and Reliability Test}

The results of the validity and reliability tests of the instrument were carried out using SPSS by looking at the loading factor value on the rotated component matrix of each instrument. The results of the validity test show that the value of each instrument has a loading factor value of $>0.6$ so it can be concluded that it is statistically valid. Meanwhile, the reliability test results show that the value can be explained in table 2 . 
Table 2. Respondent Description

\begin{tabular}{lcc}
\hline Age (years) & Number & Percent \\
\hline $21-30$ & 8 & $8.89 \%$ \\
\hline $31-40$ & 12 & $13.33 \%$ \\
\hline $41-50$ & 35 & $38.89 \%$ \\
\hline $51-60$ & 10 & $11.11 \%$ \\
\hline$>60$ year & 25 & $27.78 \%$ \\
\hline Gender & & \\
\hline Male & & \\
\hline Female & 50 & $55.56 \%$ \\
\hline & 40 & $44.44 \%$ \\
\hline Profession & & \\
\hline Farmer & & \\
\hline Trader & 50 & $55.56 \%$ \\
\hline Entrepreneur & 20 & $22.22 \%$ \\
\hline Government employee & 10 & $11.11 \%$ \\
\hline Education level & 10 & $11.11 \%$ \\
\hline Elementary school & & \\
\hline Junior high school & & \\
\hline Diploma & 15 & $16.67 \%$ \\
\hline Undergraduate & 30 & $33,33 \%$ \\
\hline Postgraduate & 10 & $11.11 \%$ \\
\hline & 20 & $22.22 \%$ \\
\hline
\end{tabular}

\section{Validity Test and Reliability Test}

The results of the validity and reliability tests of the instrument were carried out using SPSS by looking at the loading factor value on the rotated component matrix of each instrument. The results of the validity test show that the value of each instrument has a loading factor value of $>0.6$ so it can be concluded that it is statistically valid. Meanwhile, the reliability test results show that the value can be explained in table 3 .

The results of the validity and reliability test of the hospital handling complaint variable shows that the fourth question item (X1.4) shows a result $<0.5$ so it was invalid and had to be excluded in further testing. The results of the validity and reliability test of the patient satisfaction variable shows the fourth (X3.4) and fifth (X3.5) question items shows the results $<0.5$ so they are invalid and must be excluded in further testing. The result of the validity and reliability test of the patient loyalty variable shows that the first question item (Y.1) shows the result $<0.5$ so it is invalid and must be excluded in further testing. 
Table 3. Validity and Reliability Questionnaire Test

\begin{tabular}{|c|c|c|c|c|}
\hline & & & & \\
\hline & 1 & 2 & 3 & 4 \\
\hline X1.1 & .789 & & & \\
\hline $\mathrm{X} 1.2$ & .771 & & & \\
\hline $\mathrm{X} 1.3$ & .772 & & & \\
\hline $\mathrm{X} 1.4$ & .485 & & & \\
\hline $\begin{array}{l}\mathrm{X} 1.5 \\
\end{array}$ & .706 & & & \\
\hline $\mathrm{X} 2.1$ & & .662 & & \\
\hline $\mathrm{X} 2.2$ & & .736 & & \\
\hline X2.3 & & .645 & & \\
\hline $\mathrm{X} 2.4$ & & .705 & & \\
\hline $\mathrm{X} 2.5$ & & .664 & & \\
\hline $\mathrm{X} 3.1$ & & & & .823 \\
\hline $\mathrm{X} 3.2$ & & & & .775 \\
\hline X3.3 & & & & .653 \\
\hline X3.4 & & & & .452 \\
\hline X3.5 & & & & .182 \\
\hline Y.1 & & & .481 & \\
\hline Y.2 & & & .551 & \\
\hline Y.3 & & & .567 & \\
\hline Y.4 & & & 678 & \\
\hline $\begin{array}{l}Y .5 \\
\end{array}$ & & & .566 & \\
\hline
\end{tabular}

\section{RESULT AND DISCUSSION}

\section{Research Result}

Hypothesis test in this study was carried out through statistical testing with the path analysis approach in testing mediation regressions which can be explained in table 4. and table 5 . The results of testing for hypothesis 1 to hypothesis 3 can be explained as follows.

Table 4. Multiple Regression Testing Results Hypothesis 1 and Hypothesis 2

\begin{tabular}{llllll}
\hline $\begin{array}{l}\text { Handling complaint and Patient } \\
\text { satisfaction }\end{array}$ & $\begin{array}{l}\text { Predictor } \\
\text { Variables }\end{array}$ & $\boldsymbol{\beta}$ unstd. & $\boldsymbol{\beta}$ std. & $\mathbf{t}$ & Sig \\
\hline $\begin{array}{l}\text { Dependent variable : Patient satisfaction } \\
\text { Adj. } \mathrm{R}^{2} 0.074 \text { - sig } 0.009\end{array}$ & $\begin{array}{l}\text { Handling } \\
\text { complaint }\end{array}$ & 0.140 & 0.272 & 2.654 & 0.009 \\
\hline
\end{tabular}

Table 5. Multiple Regression Test Results for Hospital SERVQUAL

\begin{tabular}{lccccc}
\hline Hospital SERVQUAL & $\begin{array}{c}\text { Predictor } \\
\text { Variables }\end{array}$ & $\boldsymbol{\beta}$ unstd. & $\boldsymbol{\beta}$ std. & $\mathbf{t}$ & Sig \\
\hline $\begin{array}{l}\text { Dependent variable : Patient satisfaction } \\
\text { Adj. } \mathrm{R}^{2} \quad 0.057 \text { - sig } 0.024\end{array}$ & $\begin{array}{c}\text { Hospital } \\
\text { SERVQUAL }\end{array}$ & 0.179 & 0.238 & 2.301 & 0.024 \\
\hline
\end{tabular}


Table 6. Results of Mediating Regression Test for handling complaints, hospital servqual, hospital satisfaction on loyalty

\begin{tabular}{lccccc}
\hline $\begin{array}{l}\text { Handling complain, Hospital servqual, } \\
\text { hospital satisfaction on loyalty }\end{array}$ & $\begin{array}{l}\text { Predictor } \\
\text { Variables }\end{array}$ & $\boldsymbol{\beta}$ unstd. & $\boldsymbol{\beta}$ std. & $\mathbf{t}$ & Sig \\
\hline $\begin{array}{l}\text { Dependent variable }: \text { loyalty } \\
\text { Adj. } \mathrm{R}^{2} \text { 0.053- sig } 0.030\end{array}$ & $\begin{array}{c}\text { Patient } \\
\text { satisfaction }\end{array}$ & 0.261 & 0.230 & 2.212 & 0.030 \\
\hline
\end{tabular}

Statistically, the test results on hypothesis 1 which tests the relationship of handling complaints on hospital satisfaction are shown in Table 6. Table 6. shows the results of the regression coefficient value of the relationship between hospital handling complaints on patient satisfaction which is indicated by a value $(t=2.654>1.96)$ with a significance value $(0.009<0.05)$. These results indicate that hospital handling complaints have an effect on patient satisfaction. Hypothesis 1 is accepted.

Hypothesis 2 test results show the results of the regression coefficient value of the relationship between hospital SERVQUAL on patient satisfaction as indicated by the value $(\mathrm{t}$ $=2.301>1.96)$ with a significance value $(0.024<0.05)$. These results indicate that SERVQUAL hospital has an effect on patient satisfaction. Hypothesis 2 is accepted.

Hypothesis 3 test results show the results of the regression coefficient value of the relationship between patient satisfaction on loyalty which is indicated by value $(t=2.212>$ $1.96)$ with a significance value $(0.030<0.05)$. These results indicate that patient satisfaction has an effect on loyalty. Hypothesis 3 is accepted.

\section{Discussion}

The results of the first hypothesis test indicate that handling complaints have an effect on patient satisfaction. The results of this research are in accordance with previous research which states that complaint handling can be used as an important instrument in controlling conflicts between hospitals and patients about dissatisfaction (Kau and Loh 2006). In addition, it is also explained that the handling of complaints by the hospital is a tool to increase the profit of the hospital (Salazar et al. 2013).

The results of the second hypothesis test indicate that the SERVQUAL hospital has an effect on patient satisfaction. The results of this study are in line with previous research which states that there is a relationship in service quality and patient satisfaction (Vinagre and Neves 2008). Several previous studies also support this study which states that there is a relationship between service quality, patient satisfaction, hospital operational utilization measures, and hospital financial performance (Duggirala et al. 2008).

The results of the third hypothesis test show that patient satisfaction has an effect on loyalty. The results of this study are in line with previous studies with the findings that hospital customer satisfaction affects patient loyalty (Wu 2011). Study by Fatima et al. (2018) is in line with the results of this study which find that health care providers need to strive to provide better health services to their customers.

\section{CONCLUSION}

This study makes an important contribution in examining the mediating role of patient satisfaction in achieving patient loyalty. It has practical and theoretical consequences. This 
study provides important recommendations for future research, including the need to develop a more comprehensive empirical research model on patient characteristics in using company services.

\section{REFERENCE}

Bowen, J. T., and S.-L. Chen. 2001. The relationship between customer loyalty and customer satisfaction. International Journal of Contemporary Hospitality Management Decision vol. 13/5:pg. 213-217.

Duggirala, M., C. Rajendran, and R. Anantharaman. 2008. Provider-perceived dimensions of total quality management in healthcare. Benchmarking: An International Journal.

Fatima, T., S. A. Malik, and A. Shabbir. 2018. Hospital healthcare service quality, patient satisfaction and loyalty. International Journal of Quality $\mathcal{E}$ Reliability Management.

Hur, W. M., Y. Kim, and K. Park. 2013. Assessing the Effects of Perceived Value and Satisfaction on Customer Loyalty: A 'Green' Perspective. Corporate Social Responsibility and Environmental Management 20 (3):146-156.

Kau, A. K., and E. W. Y. Loh. 2006. The effects of service recovery on consumer satisfaction: a comparison between complainants and non-complainants. Journal of Services Marketing.

Lim, J., K. Lim, J. Heinrichs, K. Al-Aali, A. Aamir, and M. Qureshi. 2018. The role of hospital service quality in developing the satisfaction of the patients and hospital performance. Management Science Letters 8 (12):1353-1362.

Mithas, S., N. Ramasubbu, M. S. Krishnan, and C. Fornell. 2006. Designing web sites for customer loyalty across business domains: A multilevel analysis. Journal of Management Information Systems 23 (3):97-127.

Oliver Richard, L. 1997. Satisfaction: A behavioral perspective on the consumer. New York ' NY: Irwin-McGraw-Hill.

Salazar, G., K. Quencer, S. Aran, and H. Abujudeh. 2013. Patient satisfaction in radiology: qualitative analysis of written complaints generated over a 10-year period in an academic medical center. Journal of the American College of Radiology 10 (7):513-517.

Skalen, C., L. Nordgren, and E. M. Annerbäck. 2016. Patient complaints about health care in a Swedish County: characteristics and satisfaction after handling. Nursing open 3 (4):203-211.

Tronvoll, B. 2007. Complainer characteristics when exit is closed. International Journal of Service Industry Management.

Vinagre, M. H., and J. Neves. 2008. The influence of service quality and patients' emotions on satisfaction. International journal of health care quality assurance.

Wu, C.-C. 2011. The impact of hospital brand image on service quality, patient satisfaction and loyalty. African Journal of Business Management 5 (12):4873-4882.

Wu, I.-L., and Y.-P. Hu. 2012. Examining Knowledge Management Enabled Performance for Hospital Professionals: A Dynamic Capability View and the Mediating Role of Process Capability. Journal of Assosiation of Information Systems Volume 13. Issue 12:pg. 976. 